\title{
Notes on isolation of Leptolyngbya (plectonema) nostocorum capable to withstand liquid hands detergent
}

\author{
Ahmed D. El-Gamal \\ Botany and Microbiol. Dept., Fac. of Sci., Al-Azhar Univ., \\ Cairo, Nasr City, P.O.Box 11884, Egypt
}

\begin{abstract}
:
The pattern growth of Leptolyngbya (plectonema) nostocorum on layer of porcelain of washing basin was remarkable, such finding attracts our interest to conduct this research. Despite the unfavorable conditions, the growth of alga was not affected. It was subjected to pressure as a result of flowing of water from tap with ranges from 0.1- 7.6 liters per minute. This process is daily repeated for about 10 times a day for periods of up to 2.5 hours. The light intensity was 100 lux and the temperature ranges between $25-30{ }^{\circ} \mathrm{C}$ as a result of process of opening and closing the tap, respectively. In addition to the previous stress, organism has been exposing to the amount of liquid soap to wash hands as a result of daily non-stop process of human activities. Description and identification of algae has been made. Basic physical and chemical analysis of tap water has been also conducted, drinking water in Saudi Arabia is stored in underground tanks and replenished as water runs out. The analysis of the water showed that $\mathrm{pH}$ was alkaline (8.7) and the total soluble salts was $56.7 \mathrm{mg} / \mathrm{L}$. The total alkalinity was $28 \mathrm{mg} / \mathrm{L}$ as well as the total hardness was $18 \mathrm{mg} / \mathrm{L}$, Calcium hardness, Magnesium hardness were 14,4 $\mathrm{mg} / \mathrm{L}$, respectively. Calcium, Magnesium and Chloride are represented at concentrations of 5.6, 0.96 and $4 \mathrm{mg} / \mathrm{L}$, respectively. The concentration of nitrate was 0.56 and the concentration of iron was $0.18 \mathrm{mg} / \mathrm{L}$. For the growth curve of alga, the best growth $(0.271$, $2630.46 \mathrm{mg} / \mathrm{L}$ ) was achieved for optical density, dry weight, respectively after 16 days of incubation. For different concentrations of the detergent, it was found that the least concentration did not have any inhibition zone to the growth of alga was $0.2 \%$. Above this concentration, there has a steady increase in the diameter of inhibition zones.
\end{abstract}

Keywords: Analysis of the water, hands detergent, inhibition zone, Leptolyngbya (plectonema) nostocorum, Saudi Arabia. 


\section{Introduction}

The climate of Saudi Arabia is characterized by severe drought with high temperatures causing scarcity of living organisms, especially algae. Makkah region relies on desalinated water from the sea for daily use and as a result of the drought and increasing of water use, there are permanent deficit of the amount of water and this in turn causes changes in the nature of the existing algal flora and makes it always conditioned by the presence of gelatinous sheaths that protect and cover them from high temperatures. Cyanobacteria are characterized by their adaptation to such conditions especially filamentous species. Cyanobacteria flora is still unknown cryptically, especially in tropical and arid regions such as Saudi Arabia (Mohamed and Al-Shehri, 2008). The dominant genera of filamentous cyanobacteria in hot desert soils are Microcoleus, Phormidium, Plectonema, Schizothrix, Nostoc, Tolypothrix and Scytonema (Shields and Drouet, 1962) Several phototrophic microorganisms, principally Cyanobacteria and chlorococcal green algae have been reported to occur as biofilms on the exposed surface of stone substratum of culturally important monuments or any layers of rocks and porcelain and building blocks, especially in humid environments of several countries of the globe (Darienko and Hoffmann, 2003; Gärtner and Stoyneva, 2003; Uher et al., 2006). Such communities accelerate the weathering of the substratum they colonize, hence considered as potential threat to the monuments (Adhikary and Kovacik, 2010). Leptolyngbya is a cosmopolitan world distribution genus evidently widespread in terrestrial, freshwater and marine habitats. John et al. (2002) on their account of the British cyanobacteria has shown that the narrow trichomes (about $2.5 \mu \mathrm{m}$ in diameter ), in sheaths that are colorless to distinctly yellow under microscope, do not easily match any of Lyngbya or Phormidium. It was noted that recent studies have moved many of these taxa into a new genus, Leptolyngbya Anagnostidis \& Komárek characterized by narrow trichomes and firm, narrow sheaths. The genus Plectonema resembles Lyngbya in that single trichomes are enclosed in gelatinous sheaths, which tend to be thin, firm and often colored. It differs from Lyngbya primarily by the occurrence of false branching. Issa and Ismail (1994) were found some algal species were very sensitive to all detergents used while others were tolerant to the 
same detergents and sensitive to others. Such results have been reported by Yamane (1984) and Abdel-Hamid (1986). The tested synthetic detergents inhibited completely the growth of Chlorella pyrenoidosa and Thalassiosira pseudonana at concentrations above $10 \mathrm{mg} / \mathrm{l}$ (Kondo et al., 1984).

The research is the first study to isolate this alga in Saudi Arabia with attention to the effect of synthetic detergents on algal growth and to reach the appropriate concentration of detergent that does not interfere with its growth as well as inhibit organism activity.

\section{Materials and Methods}

Alga was isolated from a hand washing basin from Makkah AlMukarramah Teachers' College Which lies between latitudes and longitudes with coordinates of $21^{\circ} 25^{\prime} 21.0360^{\prime \prime} \mathrm{N}$ and $39^{\circ} 49^{\prime} 34.2048^{\prime \prime} \mathrm{E}$, respectively (Fig. 1) in 2013, isolation and re-cultivation of alga was carried out by Scratching the algal growth by sterilized sharp blade and then immediately transferred to sterilized Petri dishes containing solidified Z- medium (Staub, 1961). The culture was incubated under continuous light intensity at 200 lux and the temperature was at $25{ }^{\circ} \mathrm{C}$. Growth of cyanobacterium began to appear after about 2 weeks in $\mathrm{Z}$ medium and incubated at a temperature of $25-30^{\circ} \mathrm{C}$ and light intensity up to 100 lux for a period up to 28 days. Identification of alga was done according to Alwathnani and Johansen (2011). The nature of algal growth was photographed in the wash basin as well as the growth pattern in Petri dishes containing Z-solid medium was observed. Analysis of the physical and chemical properties of water was conducted according to (APHA, 2005).

Inhibition zone activity test: Standard wells were made on the agar plate $(1 \mathrm{~cm}$ in diameter). One $\mathrm{ml}$ of the detergent at different concentrations were added into the wells and incubated for 5 days at room temperature. Then the diameters of the zones of inhibition were measured in millimeters. 


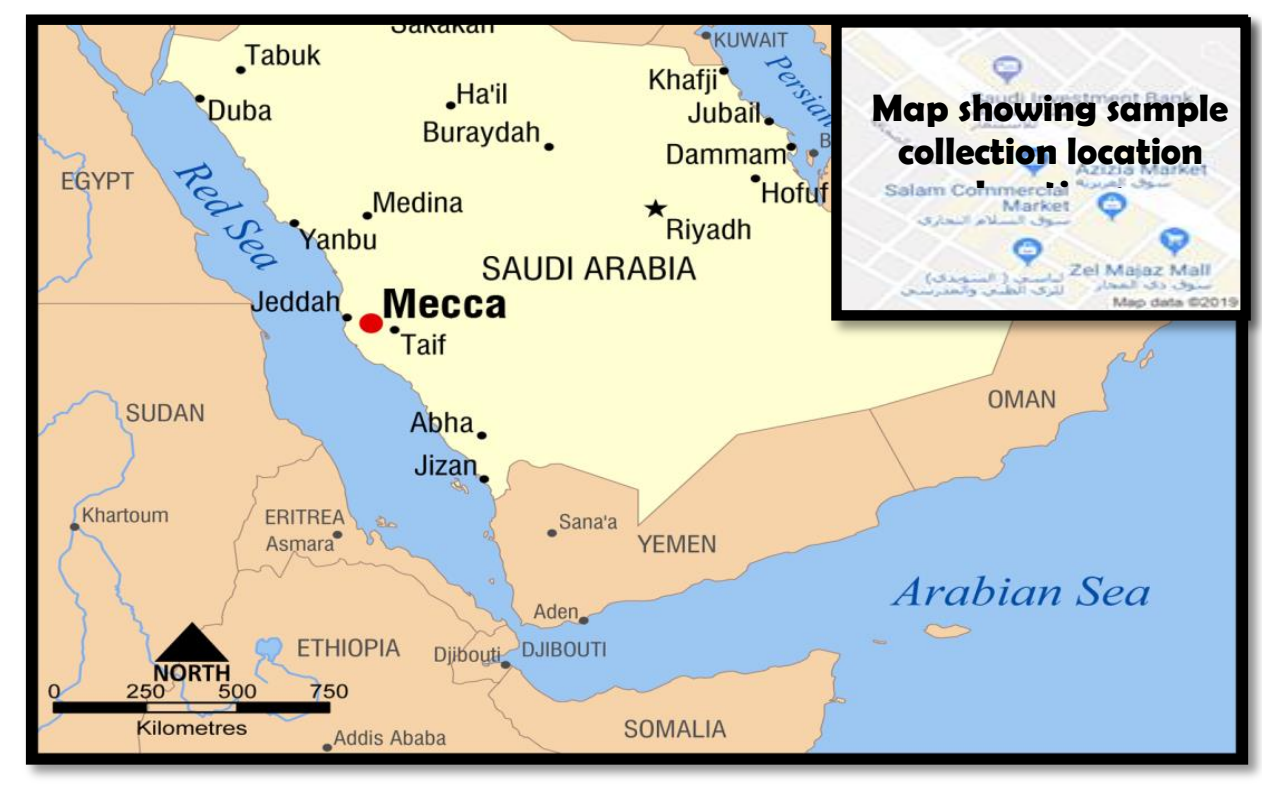

Figure (1): The location of Makkah and a map showing the locations of the samples.

\section{Results}

Leptolyngbya nostocorum (Bornet ex. Gomont) Anagnostidis \& Komárek (Pl.3, Fig. 23)

Synonym: Plectonema nostocorum Borent ex Gomont 1892.

\section{Description of species (figs. $2 \& 3$ ) (1000 X magnification)}

Thallus densely intertwined like carpet forming mucilaginous masses, sheath thin , colorless adherent to cells, can be seen clearly at the ends of the filaments; filaments wrapped, overlapping sometimes spiral or tortuous. Cells quadrate or short barrel-shaped, (1-)1.5-2(-2.5) $\mu$ width, 1-2(-3) $\mu$ length, clearly constricted at the cross walls. Trichomes fragile, fragmented. Branches, few 
usually solitary. Empty dead cells are marked between cells. Filaments (1.5-) 22.5(-3) $\mu$ in diameter. Apical cells rounded isolated from layer of porcelain of washing basin.

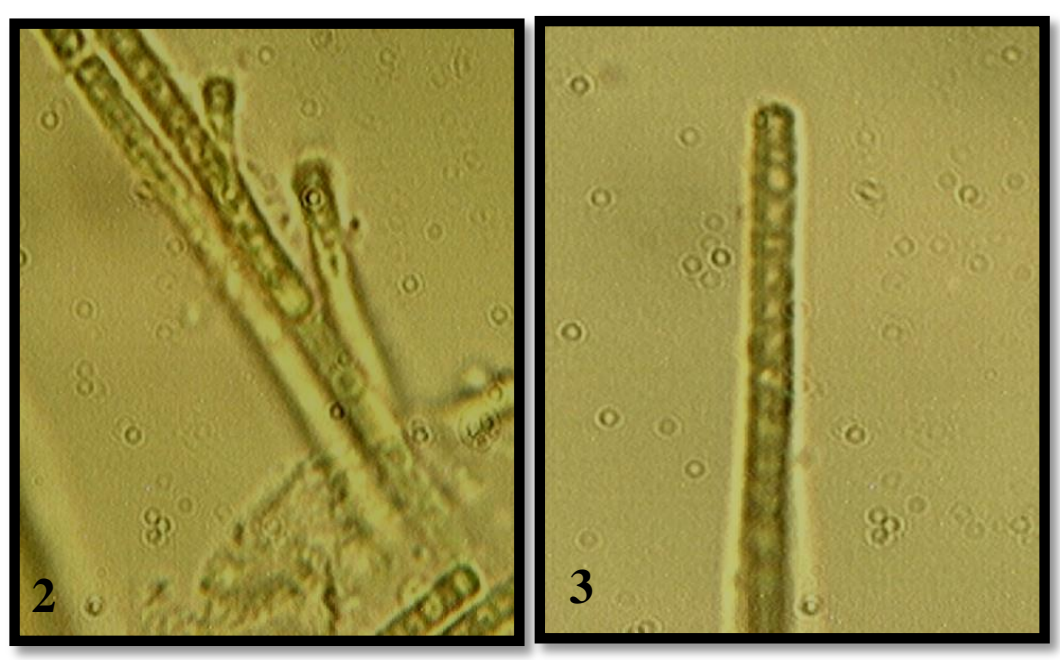

Figures (2\&3): Leptolyngbya nostocorum

Figure 4 shows the growth of alga was like thin flakes of bluish green, especially in the upper region of basin. While thick growth was increased in gelatinous form and the color thallus tended to be blackened with blue in the lower region of basin.

The growth pattern of Leptolyngbya nostocorum in Petri dishes was soft, superficial and resembling the carpet and ranged in color from bluish-green to blackish green (Fig. 5). The picture shows also color variation from gray color to brown color. 


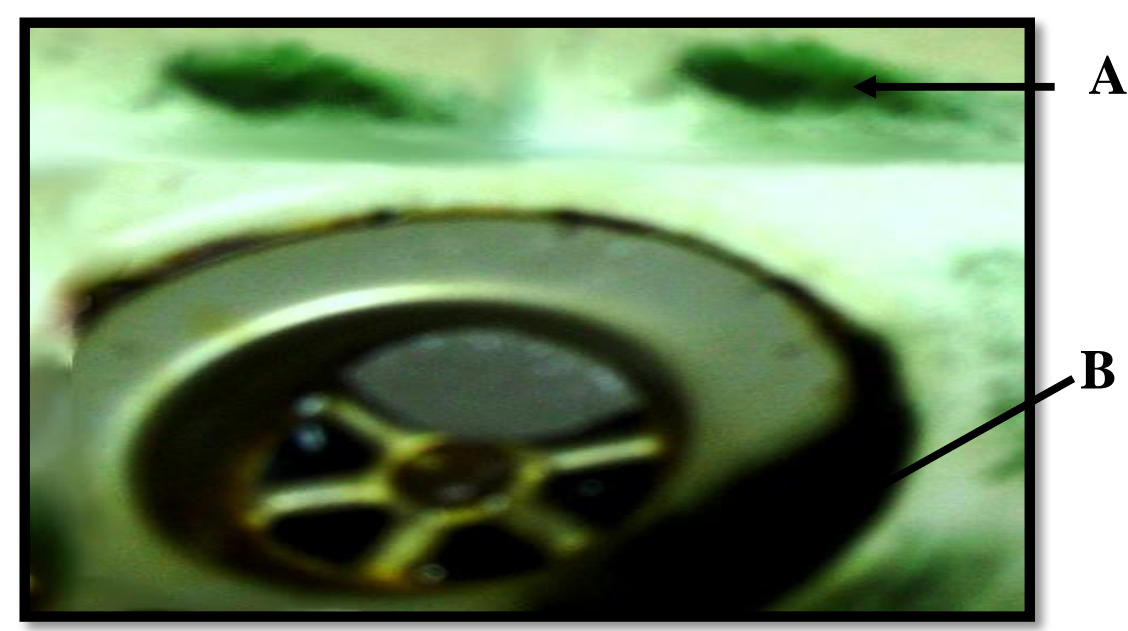

Figure (4): The growth Pattern of Cyanobacterium in the upper(A) and lower(B) parts of basin.

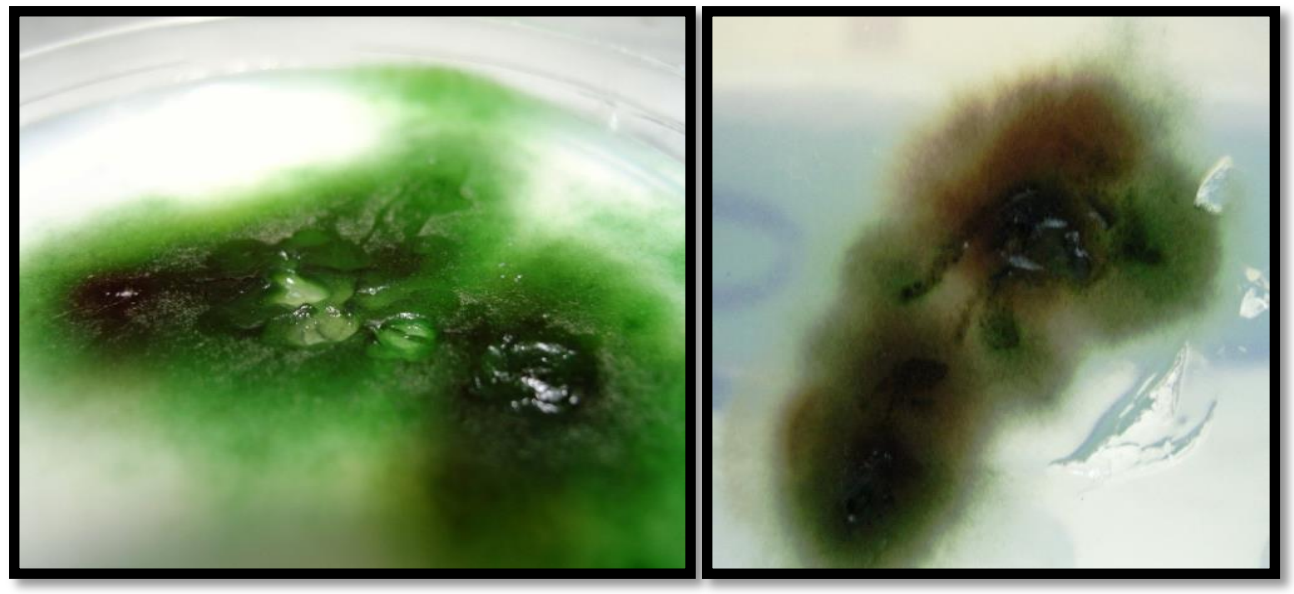

Figure (5): Growth pattern of Lyptolyngbya nostocorum in Petri dishes. 
As for the physical and chemical properties of water, Table (1) shows that the water was alkaline in nature, since $\mathrm{pH}$ was 8.7. For the odor and color of the water the results were negative. Total soluble salts recorded $56.7 \mathrm{mg} / \mathrm{L}$. As for the total alkalinity, the result was $28 \mathrm{mg} / \mathrm{L}$. Regarding the total hardness, calcium and Magnesium hardness, the results were as follows 18,14 , and $4 \mathrm{mg} / \mathrm{L}$, respectively. Calcium and magnesium values varied between 5.6 and $0.96 \mathrm{mg} / \mathrm{L}$ in water samples. For chlorides and nitrates, the results were as shown in Table (1) recorded 4 and $0.56 \mathrm{mg} / \mathrm{L}$, respectively. Nitrite and manganese were not detect, but iron record average of $0.18 \mathrm{mg} / \mathrm{L}$. Studying the growth curve of algae. It was found that the alga reached the maximum biomass in 16 days of incubation (Figs.6 A\&B), achieving optical density of 0.271 and the dry weight of 2630 $\mathrm{mg} / \mathrm{L}$ under continuous light intensity of $100 \mathrm{lux}$ and a temperature of $30^{\circ} \mathrm{C}$. After 16 days, growth of Lyptolyngbya nostocorum declined.

Table 1.Physico-Chemical Analysis of Water

\begin{tabular}{|l|c|}
\hline Parameters & Mean \\
\hline $\mathrm{pH}$ & 8.7 \\
\hline Odor & Odorless \\
\hline Color & Colorless \\
\hline Total Dissolved Solids & 56.7 \\
\hline Total Alkalinity $\left(\right.$ as $\left.\mathrm{CaCO}_{3}\right)$ & 28 \\
\hline Total Hardness $\left(\right.$ as $\left.\mathrm{CaCO}_{3}\right)$ & 18 \\
\hline Calcium Hardness $\left(\right.$ as $\left.\mathrm{CaCO}_{3}\right)$ & 14 \\
\hline Magnesium Hardness $\left(\mathrm{as} \mathrm{CaCO}_{3}\right)$ & 4 \\
\hline Calcium & 5.6 \\
\hline Magnesium & 0.96 \\
\hline Chloride & 4 \\
\hline Nitrite & N.D \\
\hline Nitrate & 0.56 \\
\hline Iron & 0.18 \\
\hline Manganese & N.D \\
\hline \multicolumn{2}{|c}{ Nesults are expressed in mg/L unless other units are mentioned) } \\
\end{tabular}




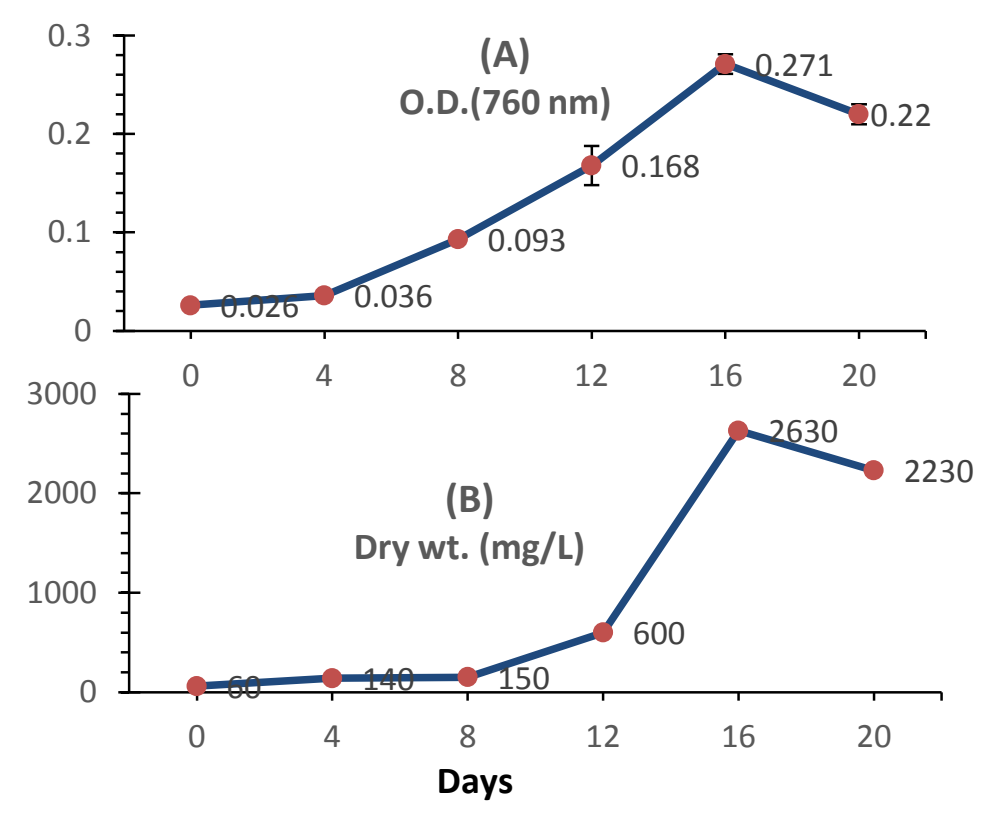

Figures (6 A \&B): Growth curve of Leptolyngbya nostocorum

In the study of the effect of different concentrations of liquid hand detergents on algal growth, the results (Table 2, Figs. 7\&8) showed that concentrations of $100 \%, 50 \%, 8.5 \%$ and $1.4 \%$ had an inhibitory effect proportional to the concentrations of the detergents, whereas the lowest concentrations had no effect on the growth. 
Table 2. Inhibition zones of different concentrations of detergent.

\begin{tabular}{|c|c|}
\hline Zone symbol & $\begin{array}{c}\text { Zones of Inhibition for Various Concentrations } \\
(\mathbf{m m}) \text { after } \mathbf{5} \text { days. }\end{array}$ \\
\hline A & $17 \pm 2$ \\
\hline B & $12 \pm 1$ \\
\hline C & $2.5 \pm 0.2$ \\
\hline D & $2 \pm 0.02$ \\
\hline E & 0 \\
\hline F & 0 \\
\hline G & 0 \\
\hline
\end{tabular}

A: $100 \%$ of concentration of detergent, B: $50 \%$ of the concentration, $\quad$ C: $8.5 \%$ of concentration, D: $1.4 \%$ of concentration, E: $0.2 \%$ of concentration, F: $0.03 \%$ of concentration, G: $0.01 \%$ of concentration.

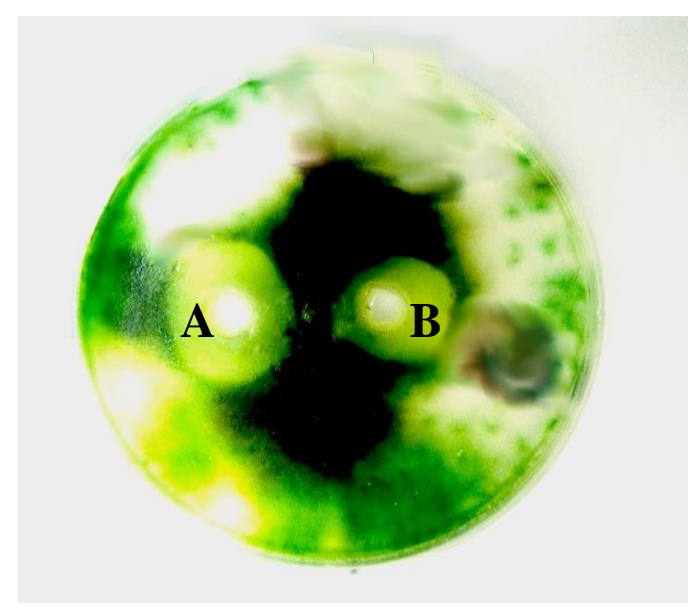

Figure (7): Inhibition zone for A (Original concentration of the detergent) and B (Half original concentration of the detergent 


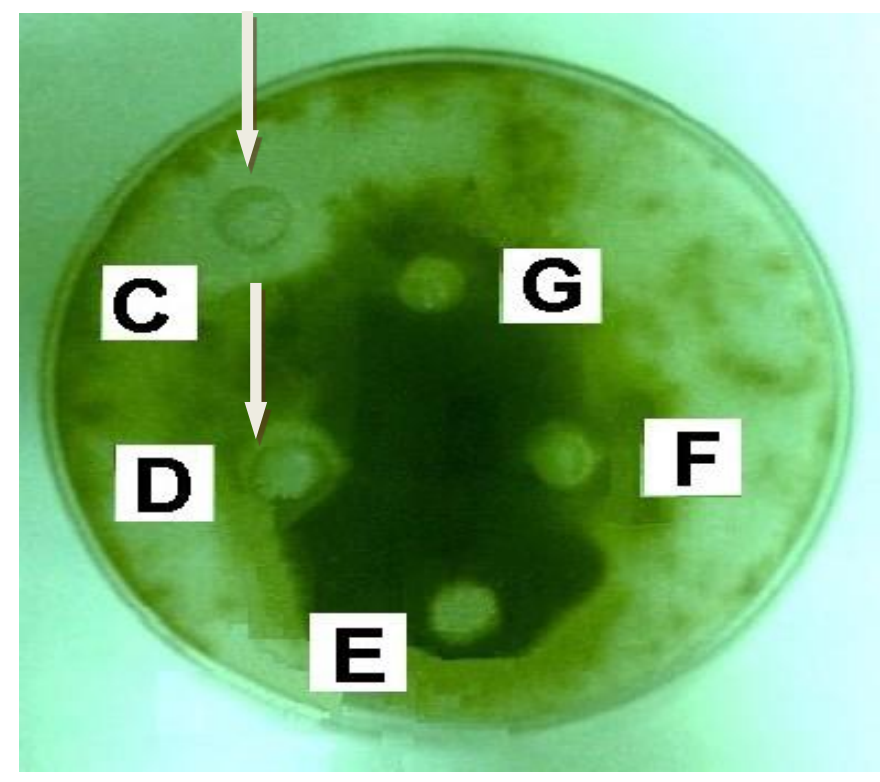

Figure (8): Inhibition zone for $\mathrm{C}$ and $\mathrm{D}$, No inhibition zones for $\mathrm{E}, \mathrm{F}$ and $\mathrm{G}$ concentration of detergent, C (8.5\%), D (1.4\%), E (0.2 \%), F (0.03\%), G (0.01\%)

\section{Discussion}

The study of algae will remain the concern of phycologists as long as explorations and research is underway. Therefore, the algae of the Arab region will remain with more scientific secrets, which will not stop until the completion of the hidden ones. This alga has attracted our attention because of its predominance in a basin that is used to wash hands with industrial detergents. The growth of alga was followed for more than a month to determine its ability to resist or was affected by the detergents used. The expected result was its ability to grow in such a poor environment in the light intensity, which did not exceed 100 lux and variable temperature due to the use or non-use of water. Leptolyngbya nostocorum was isolated and identified from hot environments, especially 
Makkah, which is characterized by high temperatures and marked drought. Despite the undisputed importance of molecular data, morphology continues to play an important role in cyanobacterial characterization (Komárek, 2010; Kauff and Büdel, 2011). In addition, the ecological characterization of the cyanobacteria and the relationship with phylogenetic assignments can now be addressed with molecular tools. It has been emphasized that ecological data are an integral part of species characterization (Komárek and Anagnostidis, 1999; Komárek 2010; Mateo et al., 2011). The identification by morphological characteristics is still the corner stone to recognition the organism in addition to some of its environmental needs and this is what has been done in the present study. Criteria such as the nature of the gelatinous sheath, color, cell description, shape and dimensions were the most important criteria used in the identification according to the usual standard methods followed. Alwathnani and Johansen (2011) isolated Leptolyngbya as the most rich species from soils of Mojave desert ecosystem which characterized by hot and dry desert. They described Leptolyngbya nostocorum in which the filaments with single trichome per sheath, with no false branching, 2.0-2.5 (3.0) $\mu \mathrm{m}$ wide. Sheaths thin, open, colorless, soft. Trichomes slightly flexuous, not tapering, very constricted at the cross-walls, without necridia, 2.0-2.5 $\mu \mathrm{m}$ wide. Hormogonia few-celled, evidently constricted at the cross-walls, and lacking sheath material. Cells blue green, becoming yellowish to washed-out brown with age, rarely with a small central granule, with thylakoids not visible in light microscopy, generally isodiametric, 2.0-2.5 (4.0) $\mu \mathrm{m}$ long. End cells slightly conical to bluntly rounded. The local form is similar to the species previously described except my form is slightly less in length. Samad and Adhikary (2008) have described such alga as thallus dark green; filament with necridic cells, hormogonia flexuous, with a very thin sheath; cells isodiametric or wider than long, 3-5 $\mu \mathrm{m}$ diameter, slightly constricted at the cross wall; apical cells widely conical, with round apex. This local findings are consistent with the few previous studies, in which green algae were shown to be dominant in temperate regions, whereas cyanobacteria dominant in the tropics, especially the forms with well developed sheaths and /or mucilage in their outer envelope. 
Regarding the physical and chemical analysis of water, municipal water is considered desalinated water from the Red sea in Jeddah and transported to Makkah via water transport lines.

The studies focused on physical and chemical analysis of rivers, canals, drains, sewage and agricultural waste-water. There is a lack of studies that deals with desalinated water analysis. Therefore, these analyzes were important where it explain the impact of drinking water treatment on existing parameters in water.

Concerning the physical and chemical properties of water, the results confirmed that the water was alkaline and $\mathrm{pH}$ was 8.7. The optimum $\mathrm{pH}$ required will vary in different supplies according to the composition of the water and the nature of the construction materials used in the distribution system, but it is usually in the range $6.5-8.5$ (WHO, 2011)

Total soluble salts recorded an average of $56.7 \mathrm{mg} / \mathrm{L}$. This result was lower than recoded by El-Gamal et al. (2019) with $271 \mathrm{mg} / \mathrm{L}$. This may be due to the different standards of desalinated water treatment from river water.

Total alkalinity recorded $28 \mathrm{mg} / \mathrm{L}$, the current results was much lower representing $14.3 \%$ of the result obtained by El-Gamal $\boldsymbol{e t}$ al. (2019). Total hardness, Ca hardness and Mg hardness recorded 18, 14 and $4 \mathrm{mg} / \mathrm{L}$, respectively. Hardness is most commonly expresses as milligrams of Calcium carbonate equivalent per liter. Although hardness is caused by cations, it may be also expressed by carbonate (temporary) and non-carbonate( permanent) hardness. Desalination of seawater and brackish water converts water with a high dissolved solids content to water with a very low dissolved solids content (WHO, 2011). Therefore, Water contained very low concentrations of elements compared with drinking water from rivers, where calcium concentration was $5.6 \mathrm{mg} / \mathrm{L}$ and magnesium $0.96 \mathrm{mg} / \mathrm{L}$,chlorides was $4 \mathrm{mg} / \mathrm{L}$, nitrates was $0.56 \mathrm{mg} / \mathrm{L}$, iron was $0,18 \mathrm{mg} / \mathrm{L}$, respectively. From an ecological perspective, isolates of Leptolyngbya were separated on the basis of their nutritional requirements. L. boryana was characteristic of waters with high concentrations of nutrients, where as $L$. nostocorum was associated with low levels of nutrients (Loza et al., 2013).

Following the growth curve of Leptolyngbya nostocorum, it was found that the highest result of growth at $30^{\circ} \mathrm{C}$ and 100 lux recorded at 16 days of incubation, 
either by determination of optical density at $760 \mathrm{~nm}$ or by calculating dry weight of algae. The results were 0.271 and $2630 \mathrm{mg} / \mathrm{L}$, respectively. Prihantini $\boldsymbol{e t}$ al. (2019) found that Leptolyngbya were likely thermo-tolerant cyanobacteria and had optimum cultured temperature $35^{\circ} \mathrm{C}$. While, optimal growth rates of Leptolyngbya isolate in BG-11 and SOT media were achieved at $30^{\circ} \mathrm{C}$ under 12 $\mathrm{h}$ light : $12 \mathrm{~h}$ dark cycles at $100 \mu \mathrm{mol}$ photons $\mathrm{m}^{2} \mathrm{~s}^{1}$. The isolate was able to grow under low-light conditions ( $<4 \mu$ mol photons $\mathrm{m}^{2} \mathrm{~s}^{1}$ Approximately $<296$ lux) (Kim et al., 2015).

From the review of the literature it is concluded that no reports on the effects of the commercial detergents on the algae of Kingdom of Saudi Arabia have been done. It therefore seems important to obtain information on the inhibitory or stimulatory effect of the detergents and to what extent they may affect such algae. In the present study of the effect of different concentrations of liquid hand detergents on algal growth, the results showed that concentrations of $100 \%, 50 \%, 8.5 \%$ and $1.4 \%$ had an inhibitory effect proportional to the concentrations of the detergents, whereas the lowest concentrations had no effect on the growth. In a similar study, Issa and Ismail (1994) were found some algal species were very sensitive to all detergents used while others were tolerant to the same detergents and sensitive to others. Such results have been reported by Yamane (1984) and Abdel-Hamid (1986). The tested synthetic detergents inhibited completely the growth of Chlorella pyrenoidosa and Thalassiosira pseudonana at concentrations above $10 \mathrm{mg} / \mathrm{l}$ (Kondo et al., 1984).

\section{References}

Abdel-Hamid, M.I. (1986). Ecological studies on the algal populations of Damietta branch and the possibility of their use as water pollution indicators. M.Sc. Thesis, Botany Department, Faculty of Science, Mansoura Univ., 290pp. 
Adhikary, S.P. and Kovacik, L .(2010): Comparative analysis of cyanobacteria and microalgae in the biofilms on the exterior of stone monuments in Bratislava, Slovakia and in Bhubaneswar, India. J. Indian bot. Soc. 89 (1\&2):19-23

Alwathnani, H. and Johansen, J. R. (2011). Cyanobacteria in soils from a Mojave Desert ecosystem. Monographs of the Western North American Naturalist, 5: 71-89.

APHA (2005). Standard Methods for the Examination of Water and Wastewater. $21^{\text {st }}$ Edition, American Public Health Association/American Water Works Association/Water Environment Federation, Washington DC.541 pp.

Darienko, T. and Hoffmann, L. (2003). Algal growth on cultural monuments in Ukraine. Biologia, Bratislava 58/4: 575-587.

El-Gamal, A.D.; Salah El Din, R. A. and Barakat, I.M.M. (2019). Dynamic case study of phytoplankton as a result of the non-biological characteristics of water at Embaba Drinking Water Station, Giza. Egypt. J. Phycol. 20: 155-181.

Gärtner, G.and Stoyneva, M.P. (2003). First study of aerophytic cryptogams on munuments in Bulgaria. Ber Nat-med Verein Innsbruck 90: 73-82.

Issa, A. A. and Ismail, M.A. (1994). Effects of detergents on river Nile water microflora. Journal of Islamic Academy of Sciences 7(3): 157-162.

John, D. M.,Whitton, B.A. and Brook, A.J., ed. (2002). The freshwater algal flora of the British Isles, Cambridge University Press, Cambridge. 702pp.

Kauff, F. and Büdel, B. ( 2011). Phylogeny of cyanobacteria. An overview. Prog. Bot., 72:209 - 24.

Kim, J.H ; Choi, W ; Jeon, S.M T.; Kim, P.A.; Kim, J.; Heo, S.; Oh1, C.; Shim,W.B and Kang, D.H. (2015). Isolation and characterization of Leptolyngbya sp. Kiost-1, a basophilic and euryhaline filamentous cyanobacterium from an open paddle wheel raceway Arthrospira culture pond in Korea. Journal of Applied Microbiology, 119: 1597-1612.

Komárek, J. (2010). Modern taxonomic revision of planktic nostocacean cyanobacteria: a short review of genera. Hydrobiologia, 639: 231-243. 
Komárek, J. and Anagnostidis, K. (1999). Cyanoprokaryota. I. Chroococcales. In: Ettl, H., Gärtner, G., Heynig, H. and Mollenhauer, D., Eds., Süßwasserflora von Mitteleuropa, Begründet von A. Pascher Bd. 19/3 Cyanoprokaryota. 1. Teil Chroococcales, Spektrum, Akademischer Verlag, Heidelberg \& Berlin, 1-548.

Kondo, M.; Yamamoto, H. and Arakawa, Y. (1984). Effects of detergents on algal growth and physiological activities. Water Pollution Research, 7 ( 9): 570-575.

Loza,V.; Berrendero, E.; Perona, E. and Mateo, P. (2013). Polyphasic characterization of benthic cyanobacterial diversity from biofilms of the Guadarrama river (Spain): morphological, molecular and ecological approaches. J. Phycol. 49: 282-297.

Mateo, P.; Perona, E.; Berrendero, E.; Leganés, F.; Martin, M. and Golubić, . S. ( 2011). Life cycle as a stable trait in the evaluation of diversity of Nostoc from biofilms in rivers. FEMS Microbiol.Ecol., 76:185-98.

Mohamed, A. Z. and Al-Shehri, M. A. (2008). Cyanobacteria of Surface and Ground Waters in Asir region with New Records to kingdom of Saudi Arabia. JKAU: Sci. 20 (2): 113-129.

Prihantini, N.B.; Pertiwi, Z.D; Yuniati, R.; Sjamsuridzal, W. and Putrika, A. (2019). The effect of temperature variation on the growth of Leptolyngbya (cyanobacteria) HS-16 and HS-36 to biomass weight in BG-11 medium. Biocatalysis and Agricultural Biotechnology. 19: 101-105

Samad, L. K. and Adhikary, S. P. (2008). Diversity of microalgae and cyanobacteria on building facades and monuments in India. Algae, 23(2): 91-114.

Shields, L.M. and Drouet, F. (1962). Distribution of terrestrial algae within the Nevada Test Site. American Journal of Botany. 49:547-554.

Staub, R. (1961). Ernährungsphysiologisch autökologische Untersuchungen an Oscillatoria rubescens D. C. Schweiz. Z. Hydrol. 23: 82-198. 
Uher, B.; Kovacik, L.; Degma, P. and Vozarova, A. (2006): Distribution of cyanobacteria and algae on building stones of Presbyterium of the St. Martin's Cathedral in Bratislava. Bull Slov Bot Spolocn Bratislava 28:11-20.

WHO (2011). Hardness in drinking-water background document for development of WHO Guidelines for Drinking water Quality. World Health Organization. Publications of the World Health Organization, $564 \mathrm{pp}$. WHO Press, Geneva, Switzerland.

Yamane, A.M. (1984). The growth inhibition of planktonic Spring water (Giant Eagle brand) algae due to surfactants used in washing agents. Water Res., 18:1101-1106. 


\title{
ملاحظات على عزل لبتولينبيا (بلكتونيما) نوستوكورم ذات القدرة على تحمل المنظفات السائلة للأيدي
}

\author{
احمد درويش الجمل \\ قسم النبات و الميكروبيولوجي, كلية العلوم (بنبين) ، جامعة الأزهر

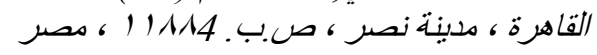

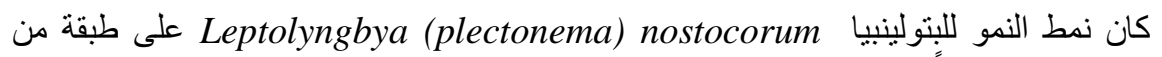

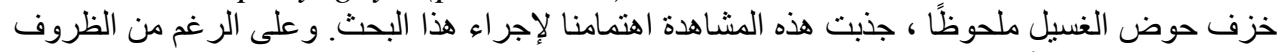

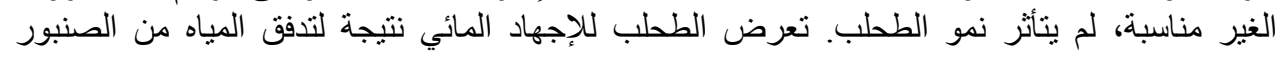

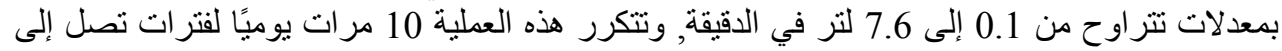

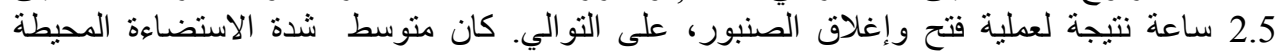

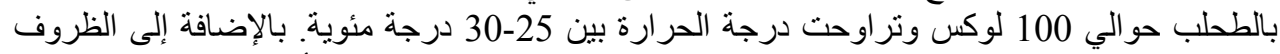

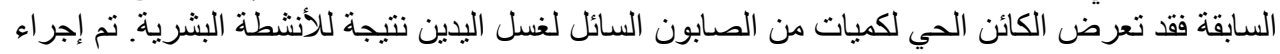

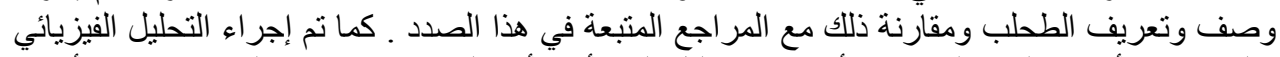

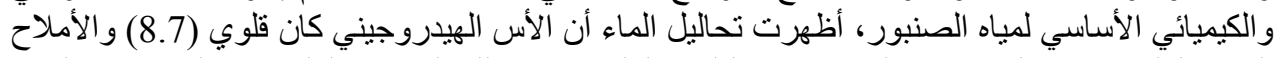

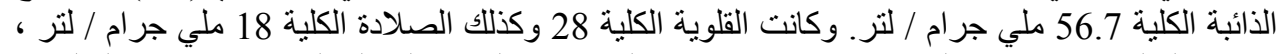

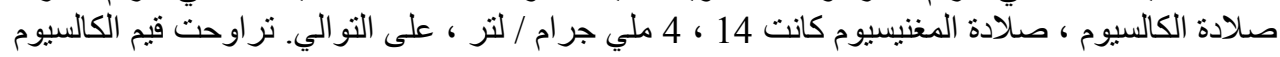

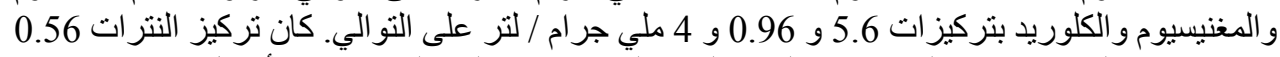

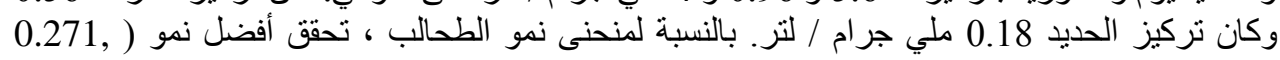

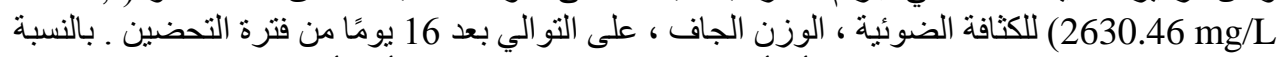

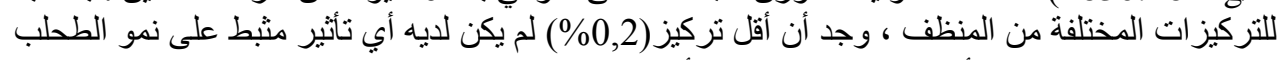

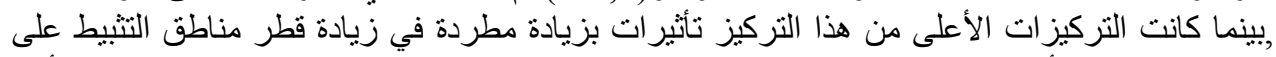

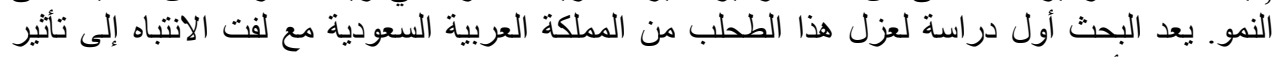
التركيزات الأولية للمنظفات السائلة في ازدهار نمو الطحالب في المسطحات المبائية. 